\title{
JOVENS EM SITUAÇÃO DE POBREZA, VULNERABILIDADES SOCIAIS E VIOLÊNCIAS
}

\author{
MARY GARCIA CASTRO \\ Pesquisadora da Unesco e pesquisadora associada à Unicamp/ \\ Centro de Estudos de Migrações Internacionais \\ castromg@uol.com.br \\ MIRIAM ABRAMOVAY \\ Consultora do Banco Interamericano de Desenvolvimento - BID \\ miabramo@globo.com
}

\begin{abstract}
RESUMO
Neste artigo são examinadas algumas dimensões centrais na vida dos jovens de 15 a 24 anos, apreendidas em pesquisa coordenada pela Unesco, sob o título Cultivando vidas. Desarmando violências. Tais dimensões foram consideradas centrais, de acordo com o acervo de trabalhos sobre jovens em situações de pobreza no Brasil, informações oficiais disponíveis e o que sentem os próprios jovens, pais e educadores. A amostra constitui-se de jovens residentes em capitais e em alguns outros municípios. A análise macrorreferenciada é entremeada de discussões dos agentes sobre o sentido, percepção e importância das dimensões examinadas'.

ADOLESCENNCIA - POBREZA - UNESCO - BRASIL
\end{abstract}

I. As referências e análises qualitativas provêm da referida pesquisa da Unesco sobre experiências de organizações não governamentais e do poder público que desenvolvem projetos nas áreas de educação para a cidadania, lazer, esporte, cultura e arte. Elas incluem jovens residentes em bairros pobres de capitais e de outras cidades nos estados do Pará, Maranhão, Ceará, Pernambuco, Bahia, Mato Grosso, Rio de Janeiro, São Paulo e Paraná. Foram realizados grupos focais e entrevistas com jovens, arte-educadores, parceiros das experiências, pais, mães e responsáveis, membros da comunidade de residência (ver Castro et al., 200 I). Recorreu-se também a diversas fontes de informação divulgadas pelo Instituto Brasileiro de Geografia e Estatística - IBGE, e pelo CNPD, 1998, e ainda a outras disponíveis no Sistema de Informação sobre Mortalidade - SIM; Departamento de Informática do Sistema Único de Saúde - SUS; Cebrid; Instituto Nacional de Estudos Pedagógicos/Ministério da Educação e da Cultura - Inep/MEC. O material coletado nos grupos focais constitui a matéria-prima desta análise. 


\begin{abstract}
This article presents some central dimensions of life for those from 15 to 24 years old from the capital cities and some Brazilian towns in the study Cultivando vidas. Desarmando violências coordinated by Unesco. These central dimensions are defined according to the reserve of information on young people in situations of poverty in Brazil and taking into account available official information in addition to what the young people, their parents and teachers have to say. These macro references are combined with excerpts from the discourse of the subjects on sensation, perception and the importance of the dimensions analyzed.

ADOLESCENCE - POVERTY - UnesCO - BRAZIL
\end{abstract}

\title{
MARCO DA ANÁLISE
}

Após uma visão panorâmica da representação demográfica da população jovem, focalizam-se temas associados ao trabalho (tipo de inserção no mercado, segundo o grau de formalidade desse, e uso do dinheiro e obstáculos percebidos para conseguir um emprego); às atividades de lazer (consideraram-se, nesse caso, mapa de equipamentos das cidades pesquisadas e oportunidades disponíveis aos jovens para ocupação do tempo livre nas comunidades de residência); às diversas formas de discriminação experimentadas por jovens, em especial provenientes do grupo social de referência.

Está implícita no plano de organização deste artigo a tese de que várias são as situações que condicionam comportamentos violentos e que "vitimam" os jovens, em particular os que vivem na pobreza.

A violência, em suas diversas facetas, é tema de análise, com ênfase em significados, manifestações e reações dos jovens, assim como o uso de drogas.

Este é um trabalho de cunho mais exploratório, em que se apresentam tãosomente dimensões e significados das situações analisadas, segundo atores que convivem com jovens em situações de pobreza, e os próprios jovens, em áreas urbanas do Brasil.

Os jovens a que se refere a pesquisa vivem em famílias com renda de até três salários mínimos per capita, sendo que muitos provêm de famílias de pais e mães desempregados; alguns já passaram por experiência de viver na rua ou estar envolvidos em atos de delinqüência. Todos estavam, quando da pesquisa de campo, freqüentando projetos/experiências que investiam em educação para a cidadania, atividades de lazer, de profissionalização em comunicação e informática, ou participavam de atividades artísticas e culturais, todas voltadas tanto para o direito de acesso a bens culturais como para a formação de valores contrários à violência, além de 
terem como expectativa afastar os jovens de situações de risco. Daí entitular-se a pesquisa da Unesco: Cultivando vidas. Desarmando violências.

\section{Marco conceitual - vulnerabilidades sociais}

Um dos conceitos nucleares deste texto é o de vulnerabilidades sociais.

O conceito de vulnerabilidades sociais tem sido utilizado por distintas agências, mas aqui vamos nos ater a algumas referências, como as de autores da Comissão Econômica para a América Latina e o Caribe - Cepal - que organizaram, em junho de 200 I, um seminário preparatório para documentos, recorrendo ao conceito para debate sobre a situação da América Latina. Parte-se do conceito corrente de debilidades, ou fragilidades, para elaborações que fogem do sentido passivo que sugere tal uso. Na elaboração mais conceitual, vulnerabilidade pede recorrência a diversas unidades de análise - indivíduos, domićlios e comunidades -, além de recomendar que se identifiquem cenários e contextos (Vignoli, 200 I; Arriagada, 200 I, Filgueira, 200 I, entre outros). Pede, portanto, diferentemente do conceito de exclusão, olhares para múltiplos planos, e, em particular, para estruturas sociais vulnerabilizantes ou condicionamentos de vulnerabilidades.

Durante la década de los noventa, el desarrollo del marco "activos-vulnerabilidad" o del a set-vulnerability-framework, para expressarlo em su terminologia original, se volvió una de las ideas mas novedosas de la literatura que estudia el fenómeno de la pobreza en las sociedades contemporáneas y en particular, en los paises de la periferia. En su concepción inicial, el nuevo marco estuvo orientado por el interés en demostrar las potencialidades de un abordaje acerca de los recursos que pueden movilizar los hogares o los individuos, sin circunscribirlo a la noción de capital en terminos exclusivamente economicos o monetarios.... Recorre a diversas disciplinas, como la sociología, la antropología y la psicología social... con la preocupación de diseno e instrumentos de políticas sociales (por ejemplo, de combate a pobreza)... identifica activos relevantes para el desempeno de los individuos, como el "capital social"... (Filgueira, 200 I, p. 2)

Com o debate sobre vulnerabilidades sociais pretende-se sair de análises de posições, morfologias estáticas, e reconhecer processos contemporâneos, remodelações de relações sociais nas quais, sublinhamos, a cultura e a subjetividade não seriam nem superestruturas, nem serendipities, turbulências laterais. Por outro lado, tentam-se compreender, de forma integral, diversidade de situações e diversidade de sentidos para diferentes grupos, indivíduos, tipos de famílias ou domicílios e comunidades. Implícitas estariam as transformações por conta de novos perfis do mundo 
do trabalho ou do não-trabalho, e, como referência mais ampla, por conta de tempos em que modernidade, diversidade e insegurança se combinam, e em que múltiplos sistemas de normas de discriminações se combinam, mas guardam identidades próprias.

Ademais, vários autores, como os citados, recorrem, por exemplo, ao conceito de vulnerabilidades sociais para tentar desconstruir sentidos únicos e identificar potencialidades de acionar atores e atrizes para resistir e enfrentar situações socialmente negativas. Haveria portanto uma vulnerabilidade positiva, quando se aprende, pelo vivido, a tecer formas de resistências, formas de lidar com os riscos e obstáculos de modo criativo. $O$ conceito constituinte desse plano de vulnerabilidade (a vulnerabilidade positiva) seria subsidiário dos debates de Bourdieu (200 I) sobre capital cultural, social e simbólico, ou seja, o que se adquire por "relações de comunicação", tomando consciência de violências simbólicas, do que aparece como arbitrário. É quando as vulnerabilidades vividas trazem a semente positiva de "um poder simbólico de subversão" (p. I5)

Avança-se, no texto de Vignoli (200 I) para o reconhecimento de que o enfoque de diretos humanos, e neste, o de direitos específicos em relação à existência de específicos sistemas de adscrições e discriminações, assim como de específicas linguagens quanto a sentidos, não deveria ser congelado como figura de retórica no discurso político, ou princípio abstrato. Em estudos sobre vulnerabilidades sociais que acessam os indivíduos, as famílias e grupos na comunidade, tende-se a trabalhar com o esperado em diferentes sistemas de linguagens, reconhecendo a força da subjetividade, do desejo, e a distância entre o vivido e o esperado quanto a direitos humanos.

É preciso, contudo, pesquisar mais sobre ambientes ou "inseguranças e incertezas" (Vignoli, 200 I; Cepal, 2000), bem como sobre o reconhecimento do direito a ter direitos, tal como o refere Hanna Arendt no debate sobre cidadania (apud Duarte 200 I). Para tanto, é necessário recorrer a diversos planos analíticos.

Análises sobre vulnerabilidades contemporâneas na América Latina, como a "juvenilização" da mortalidade, em particular entre grupos na pobreza e por causas violentas, sugeririam, por exemplo, que não basta referir-se a direitos individuais, mas também de grupos e gerações e a características de um tempo e de sociedades. Quais seriam as marcas desta geração, e de gerações nessas sociedades?

Afetam a geração dos jovens, o desencanto, as incertezas em relação ao futuro, o distanciamento em relação às instituições, a descrença na sua legitimidade e na política formal, além de resistência a autoritarismos e "adultocracia". Nesse 
caso, a escola e a família já não teriam a mesma referência que tiveram para outras gerações, além de que há diversidades quanto a construções dessas referências em grupos em uma mesma geração. Por outro lado, o apelo da sociedade de espetáculo e o apelo aos padrões de consumo conviveriam com chamadas para a responsabilidade social e o associativismo. Essas e outras tendências contraditórias também potencializariam vulnerabilidades negativas e positivas (no sentido de fragilidades, obstáculos, capital social e cultural e formas de resistência no plano ético cultural).

Dessa forma, discutir juventudes pede discutir modernidade e sua realização em distintos planos e para distintos grupos sociais.

Autores de textos que subsidiam a Reunião de Cúpula da Cepal, que será realizada em Salvador, Bahia, em 2002, e cujo tema são as vulnerabilidades sociais, ao se referirem ao enfoque de vulnerabilidade, consideram os "choques para as comunidades, lares e indivíduos", o "enfoque dos riscos" e o "enfoque dos ativos", ou a intenção de identificar "recursos mobilizáveis nas estratégias das comunidades, lares e pessoas" (Vignoli, 200 I, p. 58). Caberia, por outro lado, ter o cuidado de não incorrer em uma falácia de níveis equivocados, devendo o pesquisador estar consciente de que pode haver contradição de sentidos também entre subunidades, ou componentes de uma determinada unidade, por exemplo, entre pais e filhos, ou membros da família homens e outros membros, mulheres. Não basta, portanto, referir-se a famílias vulneráveis (Arriagada, 200 I).

Recorre-se, no léxico cepalino, junto com a vulnerabilidade, a termos emprestados da lógica de mercado, como capital social, riscos e ativos. Cabe, portanto, também investir mais na crítica dessa lógica - o que foge, por agora, ao âmbito deste texto - para que, recorrendo ao conceito de vulnerabilidade, não se escorregue no mesmo viés dos debates sobre exclusão e pobreza, como se os jovens mais vulneráveis fossem considerados não como parte, mas excluídos ou fora do sistema, o que levaria a ficar com indicadores de posição, sem avançar na análise para compreender processos e relações sociais.

Em resumo, autores que recorrem hoje ao conceito de vulnerabilidades sociais (Vignoli, 200 I ; Filgueira, 200 I ; Arriagada, 200 I) indicam a dialética possível no uso do conceito, referindo-se tanto ao negativo, ou seja, a obstáculos para as comunidades, famílias e indivíduos, assim como a riscos, quanto ao positivo, considerando possibilidades, ou a importância de se identificarem "recursos mobilizáveis nas estratégias das comunidades, famílias e indivíduos" (Vignoli, 200 I, p. 58).

Neste artigo, opta-se pelo descrito por jovens, animadores nos projetos, pais, mães e responsáveis, destacando-se o negativo - tônica comum, em particular 
nas falas dos jovens -, mas, por outro lado, alertando para a possibilidade do positivo - ou seja, a consciência quanto a riscos e obstáculos vividos e a busca de uma ética de vida que representaria um capital simbólico e cultural, que se insinua no exercício da crítica social.

\section{REPRESENTAÇÃO DEMOGRÁFICA DOS JOVENS}

Nas capitais e em alguns municípios em que foi realizada a pesquisa, a coorte entre I 5 e 24 anos correspondia, em 1998, a cerca de I/5 da população. Os percentuais encontrados variam do mínimo de 17\%, no Rio de Janeiro, e de 19\%, em São Paulo, ao máximo de 24\%, em São Luís (Tabela I). Nessas localidades a participação dos jovens na população total é superior à registrada no Brasil como um todo, em 1995 (8,5\%), o que confirma a concentração juvenil nas áreas urbanas (78\% em 1996). Praticamente não há diferenças na distribuição por sexo nessa faixa etária.

Segundo estudos sobre a dinâmica populacional do segmento jovem, ainda que acompanhando a redução do ritmo de crescimento da população, somente no período 1991/1996, em todo o Brasil, esse grupo etário cresceu a uma taxa média anual de I,7\%, contabilizando-se cerca de 3 I milhões de jovens em 1996. Note-se que, na maioria das regiões metropolitanas - RMs - (referências para algumas capitais e municípios desta pesquisa, com exceção de Recife), ocorrem taxas médias de crescimento anual da população entre I 5 e 24 anos, bem superiores ao país como um todo, a saber: Belém, 2,43\%; Fortaleza, 2,26\%; Salvador, 3, I4\%; Vitória, 3,37\%; Rio de Janeiro, I , I2\%; São Paulo, 2,5 I\% e Curitiba, 3,81\% (Oliveira et al., 1998).

Tais dados por si já sinalizam a importância de políticas públicas para esse expressivo contingente da população. Por outro lado, os dados anotados indicam o crescimento dessa coorte, em que pese a tendência recente ao envelhecimento demográfico da população brasileira. Como observa Madeira, referindo-se ao ritmo de crescimento da população entre 15 e 24 anos, seria pertinente destacar, no panorama demográfico brasileiro, uma "onda jovem", chamando a atenção para o fato de que estaríamos "vivendo um pico abrupto no número de adolescentes, cuja média gira em torno de 17 anos" (Madeira, 1998, p. 431).

\section{TRABALHO}

Vários estudos alertam para a situação de vulnerabilidade dos jovens quanto ao trabalho, sendo esse um dos contingentes populacionais que apresentam algu- 
TABELA I

POPULAÇÃO ENTRE I5 E 24 ANOS NA POPULAÇÃO TOTAL, POR SEXO, SEGUNDO CIDADES SELECIONADAS, 1998 (\%)

\begin{tabular}{lrrr}
\multicolumn{1}{l}{ Cidade } & Homens & Mulheres & \multicolumn{1}{c}{ Total } \\
\hline Belém & $23(553.204)$ & $23(616.664)$ & $23(1.169 .868)$ \\
São Luís & $23(378.660)$ & $25(436.999)$ & $24(815.659)$ \\
Fortaleza & $20(959.251)$ & $21(1.091 .542)$ & $21(2.050 .793)$ \\
Recife & $21(634.416)$ & $20(729.507)$ & $21(1.363 .923)$ \\
Camaragibe & $23(56.268)$ & $22(59.647)$ & $22(116.275)$ \\
Cabo de Sto. Agostinho & $23(72.148)$ & $22(74.353)$ & $23(146.501)$ \\
Salvador & $22(1.066 .327)$ & $23(1.202 .220)$ & $22(2.268 .547)$ \\
Cuiabá & $22(218.581)$ & $22(227.656)$ & $22(446.237)$ \\
Vitória & $20(127.022)$ & $20(141.971)$ & $20(268.993)$ \\
Rio de Janeiro & $18(2.616 .395)$ & $16(2.950 .498)$ & $17(5.566 .893)$ \\
São Paulo & $20(4.749 .910)$ & $19(5.145 .276)$ & $19(9.895 .186)$ \\
Curitiba & $20(744.178)$ & $20(804.170)$ & $20(1.548 .348)$ \\
\hline
\end{tabular}

Fonte:FIBGE, 200I. Os números absolutos correspondem ao total sobre o qual foram calculados os percentuais em cada categoria.

mas das mais altas taxas de desemprego e de subemprego no país ${ }^{2}$. Eles enfrentam problemas singulares quanto à primeira inserção no mercado, o que, em alguma

2. Em 1995, dos 4,5 milhões de desempregados no Brasil, cerca de $48 \%$ (2, I milhões) eram jovens - entre 15 e 24 anos. Ou seja, II, I\% dos jovens no mercado de trabalho, de fato, estariam procurando trabalho, na semana da coleta de dados da PNAD. Nas regiões metropolitanas havia, em 1995, "uma taxa média de desemprego juvenil da ordem de 16,2\%, sendo que no grupo social mais pobre - até meio salário mínimo per capita - essa porcentagem se eleva a 27, I \% e, no seguinte - de meio até um salário mínimo per capita -, a 20,7\%" (Arias, 1998). 
medida, deve-se à exigência dos empregadores de prova de experiência. É também uma população que tem demandado novos enfoques da educação e qualificação profissional, não acessíveis aos jovens de famílias pobres. De fato, as mudanças no mundo do trabalho, a desregulamentação e a flexibilização da economia demandariam habilidades nem sempre disponíveis entre os jovens de setores populares como conhecimentos em informática e línguas estrangeiras - isso em contexto de diminuição dos postos de trabalho para grande parte da população.

No Brasil, a população economicamente ativa - PEA - de 15 a 24 anos correspondia, em 1995, a 65,2\% dessa faixa etária, representando 18,8 milhões de jovens (Arias, 1998). Portanto, a partir da realidade atual (o que não corresponde a uma situação ideal) - haveria a necessidade de se criarem fontes de sobrevivência para grande parte da população jovem e para familiares que dependem do seu trabalho - quer no sentido de minimizar os atritos entre participação no mercado de trabalho e o investimento educacional a largo prazo, quer no sentido de investir mais na qualificação desses jovens ${ }^{3}$.

Entre os jovens com participação ativa no mercado de trabalho encontramse diferenças segundo o tipo de inserção - trabalho formal ou informal - e também por sexo, como se registra na tabela 2.

Ao se compararem os dois tipos de inserção no mercado - formal e informal - observa-se (Tabela 2) que os percentuais de jovens que realizam trabalho formal são significativamente inferiores aos que executam atividades informais. Os primeiros variam do mínimo de 15\% para ambos os sexos, em Belém, ao máximo de $27 \%$ das moças em Curitiba. Já os que executam trabalho informal são bem mais numerosos, variando do mínimo de $31 \%$, no Rio de Janeiro, para os dois sexos, ao máximo de pouco mais de 40\% de rapazes e moças, em Curitiba (FIBGE, 200 la).

\section{Situações no trabalho}

Para freqüentar os projetos de arte, cultura, esporte e outros que constavam das experiências pesquisadas, exige-se que os jovens estejam matriculados em uma

3. Importante notar que o intervalo etário de 15 a 24 anos esconde realidades heterogêneas quando o foco é participação no mercado de trabalho, em especial, em horizonte diacrônico. Segundo Arias (1998) enquanto a taxa de atividade do grupo de 15 a 19 anos caiu de 59,8\% em 1992, para 56,6\%, em 1995, já aquela relativa aos jovens entre 20 e 24 anos se manteve inalterável no período, cerca de $75 \%$. Esse autor também adverte sobre marcas de classe na relação entre juventude e trabalho. Em 1995, no Brasil, cerca de 39\% dos jovens estariam em famílias sem rendimentos ou com rendimentos per capita de apenas até meio salário mínimo. 
TABELA 2

POPULAÇÃo DE I5 A 24 ANOS NA POPULAÇÃO ECONOMICAMENTE ATIVA (PEA), POR TIPO DE INSERÇÃO NO TRABALHO (I) E POR SEXO, SEGUNDO CIDADES SELECIONADAS, 1998 (\%)

\begin{tabular}{lcccc} 
Cidade & $\begin{array}{c}\text { Trabalho } \\
\text { formal } \\
\text { homens }\end{array}$ & $\begin{array}{c}\text { Trabalho } \\
\text { formal } \\
\text { mulheres }\end{array}$ & $\begin{array}{c}\text { Trabalho } \\
\text { informal } \\
\text { homens }\end{array}$ & $\begin{array}{c}\text { Trabalho } \\
\text { informal } \\
\text { mulheres }\end{array}$ \\
\hline Belém & $15(80.973)$ & $15(52.977)$ & $33(44.1 \mid 3)$ & $35(19.232)$ \\
Fortaleza & $21(237.211)$ & $18(160.172)$ & $38(\mid 48.553)$ & $32(77.849)$ \\
Recife & $19(298.657)$ & $17(159.58 \mid)$ & $39(\mid 37.730)$ & $39(58.833)$ \\
Salvador & $18(29|| 42)$. & $16(204.15 \mid)$ & $31(103.599)$ & $33(56.834)$ \\
Rio de Janeiro & $17(1.34 \mid .159)$ & $17(770.805)$ & $31(364.223)$ & $31(364.223)$ \\
São Paulo & $23(2.175 .465)$ & $26(1.4 \mid 3.303)$ & $39(755.054)$ & $34(392.27 \mid)$ \\
Curitiba & $25(339.609)$ & $27(218.219)$ & $42(95.013)$ & $4 \mid(43.068)$ \\
\hline
\end{tabular}

Fonte: FIBGE, 200I. Os números absolutos correspondem ao total sobre o qual foram calculados os percentuais em cada categoria.

( I) Trabalho formal: trabalhadores com carteira assinada, militares e funcionários públicos estatutários. Trabalho informal: todas as demais categorias, denominadas "outros".

escola pública e, em muitas, acompanha-se o seu rendimento escolar. Considerase que o tempo de ser jovem é tempo de formação educacional, então o ideal é que não estejam trabalhando, mas também, em muitos casos, são oferecidas oportunidades aos jovens para desenvolverem atividades remuneradas no campo das experiências, como artistas e monitores.

Há um consenso de que o desejo dos jovens é se empregar logo, sendo comum a sua apreensão e de seus pais acerca do futuro. $\bigcirc$ trabalho tem uma centralidade referencial, é uma preocupação constante. Por outro lado, o emprego que muitos exercem é irregular ou instável, realidade tanto na vida dos beneficiários dos projetos como na de seus pais, muitos dos quais estão desempregados. Os depoimentos que se seguem, colhidos em grupos focais com educadores e familiares no âmbito da pesquisa, corroboram a concentração do público jovem em atividades informais, desnudando tanto as precárias situações vividas nas relações de trabalho como a vulnerabilidade a explorações (ver quadro I). 
MUITOS ESTÃO ESMOLANDO...

Muitos jovens são engraxates, fazem pequenos bicos, pequenas entregas, fazem montagens de coisas, alguma pintura, qualquer atividade que requeira baixo conhecimento. Ajudam o pai a fazer trabalho de pedreiro, vão capinar, outros são flanelinhas, e há quem trabalhe vigiando carros. Alguns, aqueles que têm um pouco de sorte, vão ser contínuos, mas a grande maioria está no mercado informal, não tem carteira assinada, não conhece seus direitos, é explorada.

Muitos estão esmolando, vendendo em feiras livres, mercados, e nos finais de semana, vendendo também nas praias. À noite muitos dos jovens também vendem na rua. (Entrevista de educadores com experiências com jovens)

\section{O significado e a importância do trabalho}

Os jovens entrevistados frisam ser de extrema importância conseguir um trabalho, como meio de sobrevivência individual e, muitas vezes, de suas famílias, ou mesmo como a forma de atingir a independência financeira necessária para se sentirem pessoas e construírem sua auto-estima, ou seja, como meio de inspirarem respeito na comunidade. Também insistem que a remuneração proporcionada pelo trabalho possibilita-lhes maior autonomia no plano das relações familiares: "não ficar dependendo do dinheiro da mãe", por exemplo.

Os jovens, a modo dos pais, enfatizam a importância do trabalho como forma de ocupação do tempo e da mente, o que os impediria de pensar em cometer qualquer infração. Assim, afirmam que, se houvesse emprego, muitos jovens não estariam envolvidos em atividades ilícitas. Segundo mães entrevistadas: "Como diz o outro: 'cabeça parada, oficina do diabo'. [...] $\bigcirc$ trabalho foi importante para o amadurecimento de meus filhos".

Contudo, paradoxalmente, o trabalho tanto pode ser meio para afastar-se das drogas como para assegurar o acesso a elas. Em alguns casos, parte do dinheiro que os jovens conseguem é usada para comprar drogas: "eu compro roupa, compro maconha, cola, crack, cocaína". 
Em outros casos, trabalho e violência se associariam, por não dependerem da vontade dos jovens e remeterem a situações que atingiriam não só os jovens, mas os trabalhadores que residem nas periferias:

O que mais preocupa é quando o cara vai para o serviço, tem que acordar às cinco horas da manhã, e aí sai e vai seguindo a estrada. Não sabe se tem um maconheiro fumando e rodeando a estrada. Isso aí é uma preocupação porque o cara trabalha e não sabe o que tem pela frente. (Grupo focal com jovens)

\section{Obstáculos percebidos quanto a ter um trabalho}

Alguns pais entrevistados reclamaram que os filhos fazem cursos profissionalizantes, mas depois, quando saem, não aplicam o conhecimento adquirido devido às dificuldades para conseguir emprego. Destacam a falta de perspectiva, em relação ao futuro, para o jovem.

As dificuldades mais comuns para os jovens conseguirem emprego, segundo os entrevistados, são:

- a alegação de falta de experiência por parte de empregadores;

- a exigência do $2^{\circ}$ grau e de conhecimentos de informática;

- a falta de preparo escolar para a competição no mercado;

- a discriminação por residirem em comunidades periféricas, o que limitaria suas oportunidades;

- preconceito racial;

- em vários casos, o envolvimento do jovem com a violência e a criminalidade seria destacado como um dos maiores impedimentos à sua inserção no mercado de trabalho, uma vez que, em diversas experiências, alguns beneficiários já cometeram pequenos delitos e esbarram na exigência do certificado de bons antecedentes para conseguir um emprego.

A esses obstáculos se somam outros, relacionados ao avanço tecnológico, dificilmente acompanhado pelas camadas de baixa renda, gerando um apartheid ocupacional e digital, segundo expressão do coordenador de um dos projetos pesquisados:

Enquanto um terço dos europeus acessa a Internet, no Brasil, só 4\% da população acessam a Internet e só $9 \%$ têm acesso a computadores, no trabalho ou em locais públicos. Desses $4 \%$ que acessam a Internet, 16\% são da classe média e apenas 4\% 
de setores populares. Essa situação já configura uma situação de apartheid digital, em que estão se formando legiões de excluídos tecnológicos. Então uma ação emergencial pra combater o analfabetismo digital é fundamental para essa população de baixa renda que precisa ter acesso ao que a tecnologia traz em termos de mercado de trabalho, oportunidades de serviço, de lazer e entretenimento, e principalmente de educação. (Entrevista com coordenador de projetos)

Pais, educadores e líderes comunitários enfatizam que a falta de alternativas de trabalho para os jovens dificultaria atingir as propostas dos projetos, bem como afastá-los de situações de violência, influenciar comportamentos e valores e incentivar posturas éticas de compromisso social.

A exclusão dos jovens, em particular das classes trabalhadoras e de setores populares, leva também ao desencanto em relação ao valor da escolaridade.

De fato vários jovens entrevistados manifestam desalento, sugerindo a perda do significado da escolaridade como credencial para o trabalho, expressão de uma conjuntura que eles próprios estranham: "Falta emprego para quem tem escolaridade ou não. Tem gente por aí formado, e não consegue emprego".

Muitos pais e animadores das experiências analisadas são bastante críticos acerca do lugar da escolarização na história de vida ocupacional de seus filhos, questionando o valor da escola em si, devido à qualidade do ensino e sua inadequação às demandas do mercado:

Uma escola que não é interessante, uma escola que na verdade não busca esse jovem, que espera que esse jovem se enquadre a uma estrutura que é defasada, um ensino pouco interessante com metodologias ultrapassadas. (Coordenadora de projetos)

Ainda que se registrem reflexões críticas sobre a relação entre o ensino formal e o engajamento no mercado de trabalho, de uma forma ambígua, também os jovens, como seus pais, buscam valorizar a escolaridade como fundamental para alcançar bons postos no mercado de trabalho: "Porque a primeira coisa que se exige para conseguir emprego é estudo, até para ser catador de lixo".

Mais consensual é a leitura dos efeitos do desemprego e do afastamento da escola no condicionamento de desencantos, na baixa auto-estima e na insegurança que, por sua vez, seriam possíveis desencadeadores de envolvimentos com violências e drogas:

Um problema é o desemprego e o outro é o pessoal não ter a questão da educação, um grande número não está estudando, uma parcela muito pequena que estu- 
da. Desemprego gera o quê? Desmotivação, baixa auto-estima; o fato de não estar estudando deixa eles despreparados para o mercado de trabalho e isso os leva a se envolver com outros tipos de atividades não saudáveis, como drogas e outras coisas. (Entrevista com diretora de projeto de ONG que trabalha com jovens)

Contudo, haveria que "relativizar", por um lado, a idéia de que o desemprego é uma situação associada tão somente à falta de escolaridade e, por outro lado, que seja um problema de grupos jovens. Informações sobre outros contingentes populacionais sugerem ser este um dos problemas de um tempo, de uma sociedade. Por exemplo, o saldo entre admissão e desligamento do emprego na população

TABELA 3

TRABALHADORES ADMITIDOS E DESLIGADOS, SEGUNDO CIDADES SELECIONADAS, EM DEZEMBRO/2000 (NÚMEROS ABSOLUTOS, SALDO E RAZÃO)

\begin{tabular}{|c|c|c|c|c|}
\hline Cidade & $\begin{array}{l}\text { (a) Total de } \\
\text { admitidos }\end{array}$ & $\begin{array}{l}\text { (b) Total de } \\
\text { desligados }\end{array}$ & Saldo $(b-a)$ & Razão (b/a) \\
\hline Belém & 4.163 & 5.246 & -1.083 & 1,26 \\
\hline São Luís & 2.604 & 3.031 & -427 & 1,16 \\
\hline Fortaleza & 9.901 & 10.829 & -928 & 1,09 \\
\hline Recife & 7.724 & 8.777 & -1.053 & 1,14 \\
\hline Camaragibe & 128 & 164 & -36 & 1,29 \\
\hline Cabo de Sto. Agostinho & 334 & 389 & -55 & 1,16 \\
\hline Salvador & 9.452 & 10.838 & -1.386 & 1,15 \\
\hline Vitória & 3.829 & 4.327 & -498 & 1,13 \\
\hline Rio de Janeiro & 43.031 & 47.311 & -4.280 & 1,1 \\
\hline São Paulo & 66.895 & 83.285 & -16.390 & 1,25 \\
\hline Curitiba & 14.439 & 19.222 & -4.783 & 1,33 \\
\hline Cuiabá & 2.864 & 3.512 & -648 & 1,23 \\
\hline
\end{tabular}

Fonte:MTE - Cadastro Geral de Empregados e Desempregados, 2001. 
total, conforme os dados do Ministério do Trabalho e Emprego - MTE - na tabela 3, mostra-se negativo em todas as cidades focalizadas, sendo particularmente elevado em Curitiba, Camaragibe, Belém, São Paulo e Cuiabá.

Os dados da tabela 3 reafirmam a tese de que não apenas os jovens têm de enfrentar os obstáculos próprios ao primeiro ingresso no mercado de trabalho, mas que devem fazê-lo em uma conjuntura adversa para a classe trabalhadora: "O desemprego afeta os jovens porque os pais não têm trabalho, isso afeta muito o jovem. Muitos, jovens ou não, vão traficar já que não encontram emprego, então vão achar jeito de ganhar dinheiro" (Grupo focal com mães).

Entre os jovens empregados também são comuns as críticas às relações de trabalho, à remuneração, sendo freqüente considerarem que o trabalho atual pouco contribui para suas vidas futuras. Reclamam da falta de reconhecimento profissional e da falta de oportunidades de mobilidade na atividade que realizam. Já entre os jovens que estão no mercado de produção artística, mesmo quando fazem esporádicas apresentações ou com baixa remuneração, são mais comuns declarações positivas sobre o que fazem, sugerindo haver compensação do ganhar pouco por estarem no que gostam, o que, por outras avaliações, dá-lhes alguma gratificação.

\section{Lazer}

Lazer pode associar-se tanto a estímulo como a antídoto contra violências.

Os indicadores sobre equipamentos culturais no Brasil justificam e reforçam a preocupação com a falta de espaços de lazer e de cultura para a população jovem, em especial para aqueles em situações de pobreza. Cerca de 19\% dos municípios brasileiros não têm uma biblioteca pública; cerca de 73\%, não dispõem de um museu; cerca de 75\%, não contam com um teatro ou casa de espetáculo, e em $83 \%$, não existe um cinema. Predominam carências também quanto a ginásios poliesportivos, já que cerca de $35 \%$ dos municípios não contam com tal equipamento, enquanto que em 64\% deles não há uma livraria (FIBGE, 1999). Na maioria das cidades capitais há menos de uma biblioteca para cada mil jovens. Já a situação quanto a cinemas também deixa a desejar. Em São Paulo, por exemplo, conta-se com 0,04 cinemas para cada mil jovens que aí moram.

Depoimentos colhidos na pesquisa corroboram as hipóteses sobre uma desigual distribuição desses equipamentos entre áreas da cidade. Nas comunidades pobres, seriam escassas as oportunidades de os jovens usufruírem de bens culturais e terem acesso ao capital cultural e artístico cultivado pela humanidade e parte do 
patrimônio nacional. Quando indagados a respeito de seu lazer, os jovens respondem que jogam bola. A praia, eventuais festas e brincadeiras também são citadas como opções de lazer. Divertem-se escutando música - gostam de ouvir rap, axé, samba, rocke funk - tocando em bandas, ensaiando em grupos de pagode, reggae, grupos de dança, andando de skate, e declaram que alguns "bebem muito". À noite, alguns passeiam, ficam pelas ruas.

Além da falta de equipamentos nas comunidades, os jovens circulam em raio restrito, segregados nos seus bairros, não necessariamente exercendo direitos de cidadania social, como, o benefício do uso da cidade em que vivem.

A carência de atividades de diversão na comunidade é explorada pelo tráfico que, em muitos lugares, marca presença, ocupando um espaço deixado em aberto pelo poder público, constituindo referência para os jovens.

\section{QUADRO 2}

\section{O TRÁFICO FORAM NOSSOS HERÓIS}

[Os traficantes] Colocaram lazer na comunidade, organizaram o futebol, coisa que a comunidade ama. Colocaram o baile funk, que na época a gente adorava. Colocaram uma série de outras atividades, assim, para animar a comunidade. Poxa, os traficantes foram os nossos heróis, entendeu? Na época, os traficantes eram os meus heróis e não os policiais.

(Grupo focal com jovens)

\section{Discriminação}

Os jovens sentem-se discriminados por várias razões: por serem jovens, pelo fato de morarem em bairros da periferia ou favelas, pela sua aparência física, pela maneira como se vestem, pelas dificuldades de encontrar trabalho, pela condição racial e até pela impossibilidade de se inscreverem nas escolas de outros bairros. Há reações contra os jovens que aprendem dança e música, e eles próprios são violentos contra os homossexuais, ou seja, reproduzem discriminações.

Na medida em que existe uma representação social da juventude como irresponsável, muitos são discriminados simplesmente por ser jovens, o que diversos enfatizam. Os adultos desconfiam deles, não acreditam na sua capacidade, o que muitas vezes rebaixa sua auto-estima, faz com que se sintam desrespeitados e maltratados: 
Eu acho isso também discriminação. No mundo de hoje, em termos de trabalho, assim o jovem é muito, vamos dizer, considerado irresponsável. Porque um erra e eles culpam geral. Todo mundo quer objetivo na vida. Pois é, eu acho as portas têm que ser mais abertas para os jovens acreditarem mais. Você não pode, hoje, julgar cem mil por causa de um. $O$ dono de empresa pensa muito, vamos dizer, assim, se tem 35 anos e eu 17: "Ah, não quero não, ele vai faltar, chegar tarde, não vai ter responsabilidade". (Grupo focal com jovens)

Um outro motivo de discriminação é o estigma de morar na periferia, que é associada com miséria, violência e criminalidade. Assim, o local de moradia, por si só, é um fator de exclusão no trabalho e na escola. Tais discriminações são reforçadas por não aceitarem, os adultos e a mídia, uma maneira de vestir que é peculiar não somente a esses jovens, os pobres, mas que no seu caso codifica-os negativamente:

Na verdade, a mídia acaba criando uma resistência da sociedade para com os jovens de periferia. Cria um paradigma em que esse jovem é qualificado como um marginal por não ter condição social de andar bem-arrumado. Então a sua pequena tatuagem, o seu short, o seu brinco, a sua condição de ser negro, por exemplo, já há uma discriminação terrível, que se torna muitas vezes um critério de avaliação, se o jovem é bandido ou não. (Entrevista com coordenador de projeto)

A percepção sobre determinados bairros, como violentos, leva a exclusões imediatas, fechando também as possibilidades de trabalho. A distinção entre ser honesto ou marginal é simplificada e está relacionada ao local de moradia, de maneira que uma sociedade excludente classifica como "marginais" os pobres:

Eu já botei vários currículos em lojas. Em uma, o gerente mandou me chamar. Eu disse que morava aqui no bairro, que eu estava fazendo o $I^{\circ}$ ano. Um dos pretextos dele para não me colocar foi porque eu era do $I^{\circ}$ ano. Eu sabia que ele não queria que eu trabalhasse lá porque eu disse que era do bairro. A discriminação é muito grande e injusta porque não existe só marginal, existe gente honesta até demais, e pessoas que gostam de zelar pela sua cultura. (Grupo focal com jovens)

Uma discriminação que violenta jovens e adultos em sua humanidade e cidadania é a que se relaciona ao racismo.

O preconceito racial é, segundo os jovens residentes em periferias dos centros urbanos, um condicionador de violências, das quais participam todos os envolvidos: "O que mais afeta os jovens na violência é o racismo; [...] Como aconteceu 
hoje comigo: eu vim trabalhar e uma moça segurou a bolsa, eu voltei e dei uma bronca nela".

O racismo manifesta-se também na seleção negativa e arbitrária das oportunidades de trabalho, confirmando os estereótipos sociais atribuídos aos negros:

\section{QUADRO 3}

\section{JULGAM SE VOCÊ É NEGRO}

Hoje em dia, já é difícil você arrumar um emprego, porque eles não olham a capacidade que você tem de profissionalismo. Julgam pela sua maneira de vestir. Como usa o cabelo; se você é negro. O racismo no Brasil é cordial. O racismo é aquele de nos atenderem bem, servir café para você tomar, conversar. Depois que você sai, ele rasga seu currículo. (Grupo focal com jovens)

A discriminação racial expressa-se, ainda, no tratamento conferido pela polícia aos jovens, quando estereótipos e preconceitos se traduzem em agressões até físicas:

\section{QUADRO 4}

\section{PREFERE PARAR O NEGRO}

[...] não está fazendo nada, é negro, vem na rua sem camisa, mão aberta, falando muito... isso é o bastante. Não é novidade nenhuma o que estou falando. Porque tem polícia assim: se está passando um branco e um negro assim, acho que ele prefere parar o negro e deixar o branco, isso aí que é racismo. (Entrevista com coordenador de projeto)

Muitos jovens seriam empurrados para o tráfico, que se apresenta como única alternativa não somente econômica, mas de exercício de algum protagonismo, ou lugar de poder:

Tem o depoimento de um jovem que eu achei lindíssimo: "Sou negro já tenho outra barreira para mim, eu sei que eu nunca vou ter uma casa boa para morar, eu sei que 
eu nunca vou ter um carro como eu gostaria de ter. Mas na minha rua, professora, tem um pessoal que faz 'aviãozinho', e acho que desse jeito eles têm mais condições. Porque olha, eles têm tênis de marca, eles andam muito arrumados. E eu que fico lá, meu pai falando que é importante ser honesto, ser isso, ser aquilo, eu não tenho nada. Então eu preciso ficar muito firme com minha cabeça para eu não ir desse lado, porque eu sei que o meu pai mora nessa favela há quinze anos, não conseguiu sair. Tudo o que a gente conseguiu fazer foi um cômodo de alvenaria". Então, para esse rapaz, o futuro é ter uma casa para morar, um carro, um emprego. E ele, de antemão, já está vendo que vai ser impossível com a sociedade que está aí. Uma sociedade seletiva, discriminatória, então ele está sentindo que ele não vai conseguir, e ele também está vendo o outro lado. (Entrevista com professor)

São múltiplas as normas de relações sociais que se pautam por discriminações. Por exemplo, também ocorre discriminação devido aos estereótipos em torno das opções de exercício da sexualidade e das atividades artísticas a elas associadas no imaginário social. Especialmente os rapazes enfrentam preconceito pelo fato de praticarem uma atividade tradicionalmente associada às moças.

Um jovem que pratica dança relata como se sente vítima de preconceito: "a maioria do pessoal aqui acha que quem dança é bicha".

Além disso, quem pratica música também pode ser discriminado e visto como "vadio, truqueiro, ladrão".

A norma de discriminação contra homossexuais e travestis pode levar a atos de extrema violência por parte dos próprios jovens:

Teve uma época que eu possuía um revólver, [...], a gente foi para a cidade; chegando lá uns travestis queriam ficar com a gente, eu não tenho nada contra, mas eles vieram para cima de mim e eu não gostei da atitude deles, puxei o revólver, comece a massacrá-los e fui dizendo: "Meu irmão, se oriente, eu não gosto de frango não, sou homem, meu irmão, você saia daqui porque eu vou acabar the matando". Dei um tiro e quando cheguei em casa deu o arrependimento... foi grande... no outro dia mesmo eu vendi o revólver, como a turma diz, vendi barato demais, dei o revólver. (Grupo focal com jovens)

Os jovens que freqüentam projetos que trabalham na área de arte e cultura seriam discriminados também em virtude do seu passado de pichadores, de membros de gangues ou porque integram um movimento (hip-hop), o que os identifica como "marginais": "Se o menino anda em grupo de pichações, de não sei quê, então eu já não quero mais nem saber dele. Então ele já é colocado de lado. Até mesmo a igreja teme desenvolver o trabalho". 
Os meios de comunicação contribuiriam para produzir uma realidade social distorcida, com modelos que a sociedade segue e que os jovens não podem alcançar:

Uma coisa também que tem de ser abolida é a ditadura da boa aparência. A boa aparência no Brasil é como ator de novela da Globo. Nós somos diferentes. Nós não temos obrigação de ter olho azul e nem cabelo liso. Nós queremos ser como Deus fez a gente, e temos capacidade. E não é nossa cor, não é nossa estatura, não é nosso peso que vai nos diferenciar de qualquer outra pessoa. (Grupo focal com jovens)

\section{VIOLÊNCIA}

Dados de diversos estudos, assim como as percepções coletadas em grupos focais na pesquisa, sugerem que, além da falta de oportunidades de trabalho e de alternativas de lazer, uma marca singular dos jovens, nestes tempos, é a sua vulnerabilidade à violência, o que se traduz na morte precoce de tantos. De fato, alguns dos autores citados e outros consideram que, se a falta de alternativas de trabalho e lazer não é traço novo na vida dos jovens de baixa renda no Brasil, o medo, a exposição à violência e a participação ativa em atos violentos e no tráfico de drogas seriam marcas identitárias de uma geração, de um tempo no qual vidas jovens são ceifadas. $\bigcirc$ que ocorreria hoje mais que em nenhum outro período da idade moderna, exceto em circunstâncias de guerra civil ou entre países. Ou seja: a violência que mata e sangra seria marca dos tempos atuais e não peculiar de uma classe, a pobre, fato que se destaca em pesquisa sobre juventude e violência em Brasilia, entre jovens de classe média e alta, que também adverte para a propriedade de se considerar a juventude no plural: "Não há um tipo único de jovem. Os jovens da periferia apresentam descontentamento por sua exclusão social agravada, circunstancialmente de forma violenta, buscam reconhecimento e valorização como cidadãos".

Com relação aos jovens de classe média, nota-se a existência de poucos estudos a respeito. Explica-se essa ausência pelo estereótipo que associa violência à miséria. As classes populares já seriam "perigosas", e as classes médias estariam em um processo de crise. Alguns estudos tendem a demonstrar que os jovens de classe média experimentam exclusão existencial em processos identitários.

Considerando-se o total de mortes por coorte, a faixa de 15 a 24 anos de idade exibe maior concentração na categoria de óbitos por "violência conjunta" (decorrentes de homicídios, agressões e acidentes de trânsito) do que na categoria de óbitos por "causas internas" (relacionadas a doenças). Essa tendência é bastante 
mais acentuada que nas demais coortes de idade. Por exemplo, no Rio de Janeiro, em 1998, enquanto as mortes por "violência conjunta" representaram 55\% do total de óbitos de indivíduos na faixa de 15 a 24 anos, na mesma cidade e período, os que faleceram pelos mesmos motivos não excederam $5 \%$, tanto entre a coorte de zero a I 4 anos como na de mais de 24 anos (Brasil, FIBGE).

Em Camaragibe, os óbitos na faixa de 15 a 24 anos foram, em 1997, 17\% devido a causas internas e 83\%, à violência conjunta. Os percentuais de 1996 são de 20\% e 80\%, respectivamente. Em Cabo de Santo Agostinho, em 1997, na mesma faixa etária, foram $16 \%$ os óbitos devido a causas internas, e $84 \%$, à violência conjunta. Em 1996, foram, respectivamente, 41\%, devido a causas internas, e $59 \%$, à violência conjunta.

De fato, como se mostra na Tabela 4, a morte devido às causas da violência conjunta assumem singular magnitude entre os jovens de 15 a 24 anos, variam do mínimo de 29\% em São Luís e 31 \% em Salvador, até o estarrecedor percentual de 97\% em Camaragibe.

Comparando-se somente as capitais de Estados, o percentual de jovens que perderam a vida por violência conjunta (comparando-se as mortes por causas internas) varia de 29\% e 31 \% (São Luís e Salvador), atinge a casa dos 50\% em Fortaleza e Belém, cresce um pouco mais em Curitiba (52\%) e Rio de Janeiro (55\%), chega a 3/5 em Cuiabá (60\%), aumentando em Vitória (64\%) e Recife (68\%) para se aproximar de 3/4 em São Paulo (74\%).

Segundo informações do Banco de Dados do Movimento Nacional de Direitos Humanos, que trabalha com matérias de jornais, em Salvador, de 1996 a 1999, a imprensa noticiou 3.369 assassinatos. O perfil da vítima típica seria: homem (92,3\% dos casos), entre I 5 a 24 anos (4I,8\%), negro (30,7\%) e de "cor" não noticiada na imprensa baiana, cerca de 68,3\%. Apenas I,0\% das vítimas seriam mencionadas como de cor branca (Comissão de Justiça e Paz da Arquidiocese de Salvador, 2000).

É preciso também considerar que no intervalo de idade entre 15 a 24 anos há oscilações em relação ao tipo de mortalidade por causas violentas. Por exemplo em relação a homicídios, segundo o Mapa da Violência //(Waiselfisz, 2000, p. 56), a morte por tal causa atingiria a marca de 37, I \% na idade de 20 anos, a de 35,4\%, aos 18 anos e a de 23\%, aos 15 anos (Dados para o Brasil, 1998).

A acentuada vulnerabilidade negativa à violência aparece claramente nas falas dos atores entrevistados na pesquisa, em que são evidenciadas as diversas facetas da violência, que produz não somente essas mortes, mas deixa seqüelas de vários tipos 
TABELA 4

ÓBITOS NA POPULAÇÃO DE I5 A 24 ANOS, POR GRUPOS DE CAUSAS, SEGUNDO CIDADES SELECIONADAS, 1998 (\%)

\begin{tabular}{lccc}
\hline \multicolumn{1}{c}{ Cidade } & $\begin{array}{c}\text { Causas } \\
\text { internas (1) }\end{array}$ & $\begin{array}{c}\text { Violência } \\
\text { conjunta (2) }\end{array}$ & \multicolumn{1}{c}{ Total } \\
\hline Belém & 50 & 50 & $100(477)$ \\
Săo Luís & 71 & 29 & $100(228)$ \\
Fortaleza & 50 & 50 & $100(552)$ \\
Salvador & 69 & 31 & $100(597)$ \\
Recife & 33 & 67 & $100(1269)$ \\
Camaragibe (3) & 3 & 97 & $100(29)$ \\
Cabo de Santo Aqostinho (3) & 20 & 80 & $100(55)$ \\
Cuiabá & 40 & 60 & $100(296)$ \\
Vitória & 36 & 58 & $100(253)$ \\
Rio de Janeiro & 31 & 69 & $100(2270)$ \\
Sẩo Paulo & 26 & 74 & $100(3821)$ \\
Curitiba & 48 & 52 & $100(446)$ \\
\hline
\end{tabular}

Fonte: Brasil, FIBGE,

Notas: (I) Óbitos por causas internas: doenças de todo tipo.

(2) Óbitos por violência conjunta: decorrentes de homicídios, agressões e acidentes de trânsito.

(3) Vale esclarecer que a assimetria desses percentuais é específica para o ano de 1998.

em suas vítimas diretas e indiretas.

Tanto os jovens como os responsáveis pelos projetos, além dos técnicos e outros membros, relatam um ambiente no qual a violência deixou de ser um componente de excepcionalidade e se disseminou a tal ponto que se naturalizou, banalizouse, passando a ser elemento comum no cotidiano das populações de baixa renda.

No depoimento de mães, evidencia-se o medo que sentem dos criminosos, o que impede a denúncia de crimes que ocorrem no bairro: "... A gente não pode nem abrir a boca pra dizer assim: 'Ele fez'. Porque ele vai e diz assim: 'Olha, ali a 
fulaninha que disse que tu fez'. Aí a polícia pega ele e diz que foi a gente que disse, aí a gente fica calada, com medo".

O discurso dos jovens reitera, várias vezes e pelas mais vívidas imagens, o ambi-

\section{QUADRO 5}

\section{QUALQUER UM JÁ VIU: NEGO MORRENDO, APANHANDO}

Porque isso aqui, qualquer um já viu - nego morrendo, apanhando. Quer dizer, eu acho que já viu, porque por mais que você seja bonzinho, você acaba não se tornando ruim, mas você tem que aprender nesse mundo. Eu era uma criança, eu também era diferente. Mas depois você começa a ver tanta coisa, eu tive que aprender a ser ruim. Porque tem aquela história - se você não bate, apanha. Se o cara tá errado, igual ele falou, o cara tava errado - se ele fosse se meter ia morrer também, então você tem que aprender o que você tem que fazer - você tem que aprender a correr. Você não deve pra polícia, mas quando solta fogos, a gente tem que correr com os traficantes. Tinha vezes, que quem não tinha nada a ver, que estava numa casa cheia de traficantes e a polícia chegava e queria matar todo mundo. Mas, por quê? Se você não corre, fica - morre. E se você corre atrás do traficante, a polícia pega e mata, então você tem que escolher o que vai fazer: Ou corre e fica com os traficantes e diz assim -"Não, eu vou conseguir fugir com eles porque os caras conhecem mais do que eu a favela e estão armados ou eu vou ficar e a polícia vai me pegar, vai bater, vai me matar." Então ninguém quer isso pra si. (Grupo focal com jovens)

ente de violência em que transcorre suas vidas:

Os jovens, de um modo geral, reclamam da violência existente entre gangues ou

\section{QUADRO 6}

\section{AMAMENTADOS AO SOM DOS TIROS}

A gente fala que fomos amamentados pelo som dos tiros. Porque várias vezes, a gente tava na rua, ou a gente tava em casa e, constantemente, era muito tiro... e tinha muita coisa que a gente via. (Grupo focal com jovens) 
galeras que dominam territórios nos bairros. Queixam-se da brutal rivalidade entre as gangues, o que afeta diretamente a sua liberdade de circulação:

Hoje em dia é isso, a gente não pode ir num bairro. Se um cara está todo arrumado, quando ele passa na rua, eles querem tomar as coisas. Não deveria ter esse tipo de gangue aí... se eu moro aqui no bairro, e vou para o [...], só porque eu sou do bairro de $[. .$.$] eles quebram o pau. Isso não podia existir. (Grupo focal com jovens)$

Entre os jovens, são comuns os relatos do seu próprio envolvimento com gangues, com tráfico de drogas, violência sexual e com a prostituição. Membros de vários projetos nas experiências estudadas têm ficha policial resultante de delitos como roubos e agressões físicas:

Antes de eu entrar no [projeto], eu vivia muito na rua. Andava junto com os "pichadores". Eu já fiz parte de gangue, ia para outras áreas brigar. A gente apanhava, mas também batia. A gente já furou gente lá. O pessoal da nossa gangue foi furado e a gente também furou juntos. (Grupo focal com jovens)

Violência enlaça-se com reações, em si violentas, em um sistema de vingança, no qual os assaltados esperam o momento oportuno de revanche:

Quando a turma me tomou o chapéu, depois de um tempo, apareceu um só deles lá na rua que eu moro, aí juntei uns colegas meus e massacramos ele. Eu acho que na hora eu pensava que estava certo, mas depois eu vi que estava errado, mas eles também não pensaram assim quando me pegaram. (Grupo focal com jovens)

\section{QUADRO 7}

\section{E MATARAM....}

Está com dois meses que ele foi para o pagode, e eu acordei de manhã com a notícia de que ele estava com um tiro na Restauração, cheguei lá, pensei que ele nem estava andando, porque disseram que tinha atingido a rótula, outros disseram que tinha torado a mão, foi só a notícia, cheguei lá, tinha pegado a orelha dele, varou do outro lado, trouxe ele para casa e pronto. [...] Meu filho nunca foi violento, não respondia, não brigava, não chegava com confusão, não dizia pornografia, se estivesse num canto e dissessem "vou dizer a tua mãe" pronto: ele saía, não respondia a ninguém. E mataram ele sem ter nem para quê. Quando eu soube, ele já estava morto, aqui é fogo, é preciso muita sorte mesmo. (Grupo focal com mães) 
Para as mães, a violência entre os jovens é corriqueira, mas, nem por isso, menos sofrida: "puxam logo uma arma, matam com revólver, tudo, é muita violência". Buscar um filho no hospital ou perdê-lo em razão de brigas, ou até mesmo sem ter motivo, é rotineiro.

\section{Violência doméstica}

Muitos dos jovens tiveram contato com a violência de forma direta ainda no ambiente familiar ${ }^{4}$. Os coordenadores dos projetos chamam a atenção para o fato de que muitos dos meninos que foram encontrados nas ruas deixaram a família por serem vítimas de maus-tratos pelos próprios pais:

Os meninos que estão na rua sempre têm uma história que vem da família. É um padrasto que espanca, uma mãe que espanca, é um abuso, um irmão, um padrasto que tenta abusar, é uma morte. Às vezes, no interior, a família se desmancha mesmo. Cada um vai para um lado, a criança fica só, fica abandonada. (Grupo focal com técnicos de projeto)

Ocorrências de violência doméstica contra meninas são também relatos que se repetem:

Já foram muitos os casos de violência familiar! Por parte de padrasto, do pai, as meninas vítimas de estupro. É uma coisa muito triste, tanto que muitos nem moram com a família, moram com uma família alternativa, tio, avô, ou algum parente mais velho. (Entrevista com coordenador de projeto)

A exposição a atos de violência no âmbito doméstico destruiria a auto-estima dos jovens, que se encontrariam inseguros, sem referências, já que os pais seriam os agressores, seus algozes.

4. Em Salvador, dados da Delegacia Estadual de Repressão contra Crimes à Criança e Adolescentes - Derca -, indicavam que 20\% das denúncias recebidas referiam-se à violência sexual, sendo que, em 65\% dos casos, a família aparecia como responsável (o pai, em 60\% e o padrasto, em 25\%) Entre os agredidos se destacavam os jovens entre 15 a 17 anos. Entre os crimes mais freqüentes contra as crianças e os adolescentes figurariam: agressão (43\%); lesão corporal (20\%); ameaça (8\%); apareceriam com uma proporção entre 6\% e 5\%, estupro, lesão corporal, atentado ao pudor, maus-tratos, atos libidinosos, sedução, ameaça de morte e outros (Carvalho, 200 I, p. 32). 
Tem muita jovem que já começa a ser violentada e espancada em casa. Acorda de manhã cedo já sendo espancada pelo pai embriagado, pela mãe que acabou de chegar, e a criança já sai para a rua desesperada. Qualquer coisa para ela, ou para ele, vai servir, que ele bata uma carteira, que cheire uma cola, que se drogue para esquecer o que aconteceu na casa da mãe: ao se levantar nem o prato de comida tinha, tinha somente espancamento. Aí a violência já começa de casa. Chega na rua, vai encontrar o quê? Mais violência. (Grupo focal com mães)

A violência doméstica seria um elemento desencadeador do que poderia ser denominado cadeia de violências ou reprodução de violências. Pais e mães violentos que têm os filhos como suas vítimas que, por sua vez, se tornariam violentos, fazendo outras vítimas.

O alerta para o terrível e perigoso efeito da violência doméstica na constituição do que se denomina cadeia de violência ou de sujeitos violentos não necessariamente se destaca com o intuito de culpar os pais ou as mães, mas para chamar a atenção para contextos de violência.

\section{Violência institucional}

Os relatos apontam para abuso de autoridade por parte de membros da justiça e do aparato policial. Os jovens se dizem vítimas de maus-tratos dos policiais, por isso não os percebem como agentes da sua segurança. Pelo contrário, para eles, na melhor das hipóteses, polícia e bandido são imagens que se confundem. Quando questionados a respeito do que mudariam no mundo, muitos respondem que acabariam com a polícia, como exemplificam falas de jovens:

\section{QUADRO 9}

\section{TINHA QUE FAZER TUDO OU APANHAVA}

Eu uma vez vinha do ensaio... os policiais me pegaram na rua e me pediram a identidade. Eu era menor, tinha 15 anos, eles colocaram uma arma no meu rosto. E me fizeram sambar, eu tive que sambar. Perguntaram se eu tocava, "Você canta?" "Canto", cantei para eles. "Você dança?" "Danço". "Você bate palma?" "Bato". "Bata palma", tinha que fazer tudo isso ou apanhava. (Grupo focal com jovens) 
A violência policial é um indutor, ou produtor, de sujeitos violentos, tornando os jovens, pela revolta, agentes de violências. $O$ depoimento de um jovem morador de uma favela descreve tal revolta e ambiência propícia ao crescimento da violência e seu incentivo pelos "homens da lei":

Eu nasci aqui, sempre vivi aqui na favela e vendo o quê? Vendo a polícia entrando, subindo a passarela ali, e já dando tiro cá dentro. E se dane quem tava no meio da rua. Eles não querem nem saber... eu cresci vendo a polícia massacrando meus familiares, meus amigos e o pessoal da comunidade. Vendo a polícia dar tapa na minha cara, esculachar minha família, minha mãe e me mandar ir embora, entendeu? Essa é uma coisa que vai despertando uma revolta, sabe? Eu era um moleque muito rebelde, muito revoltado em função de tudo isso, tudo isso. (Grupo focal com jovens)

Muitos consideram que as arbitrariedades cometidas por policiais contra a população pobre, em especial os jovens, derivariam também de um sistema de preconceitos contra os negros:

Eu acho que a polícia, apesar de ganhar pouco, deveria ser mais educada, pois só porque moramos aqui no... um bairro que $90 \%$ são negros, tem essa discriminação de ela chegar, sem procurar saber quem usa droga e quem não usa [...] ela chega batendo, às vezes leva até preso, sem a gente dever nada... Isso foi uma coisa muito humilhante que eu sofri, que vai marcar sempre a minha vida. (Grupo focal com jovens)

\section{Drogas}

O crescimento do consumo de drogas lícitas e ilícitas é indicado na tabela 5. Ao contrário do que usualmente se supõe, em São Paulo, Rio de Janeiro e Salvador, a tendência ao consumo de drogas reduziu-se entre os estudantes pesquisados. Em contrapartida, aumentou 10\% em Recife; 59\% em Fortaleza; 68\% em Curitiba; e 81\% em Belém.

Dados do Cebrid mostram que, entre 1987 e 1997, o uso freqüente de solventes por estudantes do ensino fundamental e médio, em capitais brasileiras, aumentou de 1,7\% para 2\%; o de maconha cresceu de 0,4\% para 1,7\%; o de ansiolíticos subiu de $0,7 \%$ para I,4\%; o de anfetamínicos aumentou de 0,4\% para $1 \%$, enquanto o de cocaína passou de 0, $1 \%$ para 0,8\%.

Apesar das limitações desses dados, que se restringem à população escolarizada e ao consumo, eles cumprem a função de dimensionar aproximada- 
TABELA 5

ESTUDANTES DO ENSINO FUNDAMENTAL E MÉDIO, CONSUMIDORES

DE DROGAS LíCITAS E ILÍCITAS, POR ANO DO LEVANTAMENTO, SEGUNDO CIDADES SELECIONADAS (\%) 1987/1997

\begin{tabular}{lccc}
\hline \multicolumn{1}{c}{ Cidade } & 1987 & 1997 & $\begin{array}{c}\text { Razão do } \\
\text { crescimento } \\
(1997-1987)\end{array}$ \\
\hline Belém & 13,5 & 24,5 & 1,81 \\
Fortaleza & 17,6 & 28,1 & 1,59 \\
Salvador & 22,5 & 20,9 & 0,92 \\
Recife & 23,5 & 25,9 & 1,1 \\
Rio de Janeiro & 25,6 & 22 & 0,86 \\
São Paulo & 23,5 & 18,5 & 0,79 \\
Curitiba & 15,6 & 26,3 & 1,68 \\
\hline
\end{tabular}

mente o problema do consumo de drogas entre os jovens alunos. Entretanto, ao abordar a temática das drogas é preciso distinguir claramente o consumo e o tráfico, pois embora possam estar entrelaçadas, cada uma dessas atividades leva a conseqüências diferentes.

De fato, é necessário ter em mente que: (a) o consumo inclui drogas lícitas e ilícitas, e ambas as modalidades acarretam alterações dos estados de consciência, possibilitando resultados direta ou indiretamente prejudiciais aos indivíduos; (b) não necessariamente o consumo de drogas está diretamente associado à violência, enquanto o tráfico está; (c) embora os usuários de drogas possam ser mais vulneráveis à violência, esta pode atingir - e freqüentemente atinge - inclusive os que não usam drogas e que são contra o seu consumo.

Do ponto de vista do consumo, o problema das drogas permeia o discurso tanto dos adolescentes envolvidos nos projetos constantes da pesquisa quanto dos 
pais e responsáveis. Os depoimentos que se seguem ilustram a ênfase atribuída à temática das drogas:

Se juntou com pessoas que não era para se juntar, quando eu vi, que a mãe é a última a saber, já estava muito... viciado em droga. Quando foi para eu tirar, não tinha mais jeito. Porque acho que todas as mãe aqui, têm filho que usa droga, não é? Não faz vergonha dizer, não é? (Grupo focal com pais/mães/responsáveis)

Alguns jovens dos projetos relatam conviver com o tráfico de drogas no seu diaa-dia e se assumem como usuários: "antes de chegar aqui... já cheirei cola, fumei de âmbar, cheirei dissolvente".

Vários jovens apontam as drogas como um dos principais e mais graves problemas enfrentados por eles. Na sua concepção, a morte aparece como evento próximo de jovens dependentes de drogas.

É interessante frisar que os jovens se referiram tanto às drogas ilícitas, em especial à maconha, quanto às lícitas, com destaque para as bebidas alcoólicas.

\section{Motivos do envolvimento com drogas}

O consumo de drogas lícitas, especialmente o álcool, em alguns casos, iniciase na própria família. Por ser socialmente aceito, o álcool é incorporado como elemento de sociabilidade em todas as camadas sociais. Encontram-se vários casos de alcoolismo de pais, irmãos ou parentes dos jovens.

Já a droga ilícita - os inalantes, a maconha, o crack, ou outros - começa a ser consumida geralmente fora do espaço da família, a partir de uma relação de amizade ou de pertencimento a um grupo. De fato, os relatos enfatizam que os jovens envolvem-se com drogas principalmente pelas amizades:

Tem vez que é a amizade. Porque a amizade dá a primeira vez e dá a segunda, na terceira ele já está viciado. Aí, na terceira, ele começa a roubar porque o pai ou a mãe não vai dar dinheiro para comprar maconha. Se ele não trabalha ele vai ter que roubar e quando ele começa a roubar acontece isso, porque não tem um que está aqui que vá dar dinheiro para o filho comprar maconha, porque existe cidadão que fuma maconha, todo mundo sabe que existe, mas pai e mãe não quer. (Grupo focal com mães)

Também se envolvem com drogas, segundo alguns, "porque a vida é difícil", querem sentir-se mais leves, mais contentes, e, segundo vários pais e animadores de projetos, porque "muitos carecem de referência familiar"; já o tráfico atuaria em espaços de múltiplas vulnerabilidades sociais negativas: 


\section{O TRAFICANTE ADOTA}

Aí você já deve ter ouvido dizer que o traficante adota. E adota mesmo. Se a gente não teve com os filhos os olhos bem aberto... e não quero saber se ele vai estar com 17, 18 ou 20 anos, eu vou andar atrás dele como eu ando hoje. Porque eu acho que ele precisa da minha orientação, porque se eu não ensinar, a vida vai ensinar para ele. E muitas mães, às vezes, por falta de instrução, não faz isso. Não liga para conversar com o filho, para sentar, para falar o que você fez hoje? E o seu amigo? Saber quem são os seus amigos, saber qual lição ele teve na escola e por aí... (Entrevista com membros da comunidade)

\section{QUADRO I I}

\section{EM TERMOS DE RISCOS E VULNERABILIDADES}

E no contexto onde ele vive, em termos de riscos e vulnerabilidade, a droga, a delinqüência e crime estão ali, do lado. Ele sai da casa dele na favela e na esquina, tem um desmanche. As figuras com as quais ele se identifica são o chefe do tráfico, o chefe do crime. Até porque são poucos os homens nessas famílias. A maioria das famílias são famílias monoparentais ou que tem um homem mas é um homem que, na maioria das vezes, é distante e, como referencial, quase nulo para eles. Então a referência que eles têm, em termos de modelo, são os líderes em áreas de ilegalidade. (Grupo focal com animadores de projetos)

O envolvimento com o tráfico de drogas pode estar relacionado com o financiamento do próprio vício. Porém, mais freqüentemente, no ambiente de exclusão social a que estão submetidas as comunidades em que vivem os jovens, a atividade no tráfico é uma via para a satisfação de aspirações de consumo para a qual a sociedade não oferece meios legítimos:

Chega um cara e chama para ganhar um dinheiro maior do que você ganha trabaIhando. Você está com a mente vazia, você não tem nem culpa porque quando nós 
nascemos já encontramos essas coisas todas erradas. Mas às vezes você está apertada, precisando, você não vai nem se lembrar do que você vai passar depois... Arrisca naquela hora você ir. É o que está acontecendo aqui, muito garoto aí com mente vazia, criança, adolescente, quando vê, está mais nas mãos da polícia. (Grupo focal com pais)

Eu acho que violência vem através, principalmente, da oportunidade de trabalho, a pessoa não tendo oportunidade de trabalho, não conseguindo um emprego, no desespero, ela vai entrar no tráfico. E o tráfico, pelo que dizem, eu não sei e não quero nem saber, está dando mais oportunidade para as pessoas, o salário parece que está melhor, apesar do risco de vida. (Grupo focal com jovens)

Para esses jovens, o tráfico representa a possibilidade de atingir um status social e obter respeito da sociedade. $\bigcirc$ traficante é visto como um indivíduo respeitado, que possui poder e dinheiro, algo quase inatingível em uma comunidade de baixa renda. No imaginário de vários jovens, é o traficante quem zela pelo bemestar da comunidade, na medida em que faz benfeitorias (muitas vezes substituindo o papel do Estado). Acima de tudo, é quem os respeita como cidadãos.

O jovem, eu acho que é vítima e agente dessa violência. Pela própria infra-estrutura que você tem dentro das comunidades - onde hoje em dia, muitas vezes o Estado é ausente - infelizmente existem grupos de marginais dentro das próprias comunidades que assumem esse papel do Estado. E isso é muito ruim, pois muitas vezes esses jovens sentem empatia pela ação desse grupo, você vê hoje nas comunidades, jovens de 12, 13 anos já envolvidos com o tráfico, envolvido com a violência. (Entrevista com coordenador de projeto)

Exclusões, violências várias corroem a auto-estima, minam vontades e reproduzem violências, sendo que, em muitos casos, enredam os jovens como vítimas e como agressores.

\section{Reflexões gerais - Marcas de uma Geração}

Neste artigo lida-se com riscos, obstáculos, ou seja, expressões de vulnerabilidades negativas, porém os jovens que freqüentam os projetos analisados na pesquisa apreendem certa positividade de tais vulnerabilidades, resistindo, buscando armar-se de valores por cultura de paz, ética de solidariedade e demonstrar uma perspectiva de crítica social, sem auto-inculpações ou determinismos, como se indica por suas falas sobre suas condições de vida.

Ao nos acercarmos, neste texto, de informações sobre o que se denomina 
violência, a que mata, fere e sangra, por informações sobre outras dimensões do cotidiano da vida dos jovens em situação de pobreza, como trabalho, exclusões quanto a bens culturais e oportunidades de lazer e racismo, a intenção é evitar o risco de substituir a necessária ênfase na economia política e em limites estruturais que afetam a sobrevivência física e a qualidade de vida de tais populações, por um enfoque culturalista, como suficiente para lidar com exclusões e pobreza, ou por abordagem centrada em um tipo de violência, ou em uma instituição, como o aparato de repressão ou de segurança pública. É fundamental ter em mente a sobrevivência física e a qualidade de vida das populações pobres e, dentro dessas populações, a singular vulnerabilidade social negativa dos jovens.

Não se nega a importância de reformas no sistema de segurança, controles sobre abusos de poder e desrespeito aos direitos humanos e a relação entre violência e crise de democracia e a necessidade de afirmação de um Estado de Bem-Estar (Peralva, 2000). Segundo a autora se faz necessário, no Brasil:

Construir um Estado que, em nome da sociedade civil, seja capaz de controlar eficazmente o funcionamento do conjunto das instituições, sem no entanto contradizer o princípio das liberdades individuais. [Este] é provavelmente um dos problemas mais importantes com que a democracia brasileira se defrontará em futuro próximo. (p.22)

Insistimos, também, tanto na tradicional tese sobre o papel, se não determinante, pelo menos de forte condicionamento, das desigualdades sociais para o crescimento da violência e do desencanto, sobre o futuro, em particular dos jovens em situações de pobreza ${ }^{5}$, quanto na tese de que há de se investir em valores voltados para uma cultura de paz, ética de convivência, e, mais que tolerância, reconhecimento das alteridades e da diversidade, tônica dos trabalhos que, no Brasil, contam com a colaboração da Unesco'. Ou seja, insiste-se na equação "cultivando vida e desarmando violências" pelo resgate da dignidade, da auto-estima e do direito à participação dos jovens, e a necessária formação de uma massa crítica, com responsabilidade social e canais de representação dos jovens, como também na importância de espaços de lazer, esporte, arte, cultura e educação para a cidadania.

Reconhece-se, por outro lado, que os jovens fazem parte e circulam por distintas

5. Abramo, 1994; Abramovay et al., 1999; Bercovich, Dellasopa, Arriaga, 1998; Hopenhayn, 2001; Zaluar, 1994; Jorge, 1998, entre outros.

6. Ver, entre outros, Abramovay et al., 1999; Castro, Abramovay, 1998; Castro et al., 200I. 
instituições, como a família, o mercado de trabalho e a escola; são produtores e consumidores de espetáculos e notícias, sendo produzidos por e reproduzindo formas de ser e de pensar. Por um lado respondem ao apelo do consumo, da competitividade, do individualismo e da fixação no poder - marcas de uma época, de uma geração -, mas muitos desenvolvem um pensamento crítico, buscam saídas e resistem, ainda que o horizonte do possível para os pobres seja limitado. Insistimos na parte de vulnerabilidade positiva do jovem, ou seja, na consciência crítica que se registra neste texto em relação ao vivido.

Por outro lado urge desenvolver políticas voltadas para juventude. Elas são importantes, como também as políticas de caráter universal, com corte geracional, mas não são em si suficientes, sem a crítica político-social sobre um momento, uma época, uma história, um modelo de relações sociais, de organização da sociedade no plano global e local.

Como frisam vários autores, estes são tempos de incerteza, medos e vulnerabilidades negativas, "estruturadas e estruturantes" (Bourdieu, 200 I). Não é necessariamente uma geração que está em crise, mas a crise de uma geração, entendida como um tempo na história, como um modelo de sociedade, o que vem afetando, envolvendo, de maneira singular, uma geração, um ciclo de vida - o dos jovens, em particular, daqueles em situações de pobreza, mas não marca somente a esses.

\section{REFERÊNCIAS BIBLIOGRÁFICAS}

ABRAMO, H. W. Cenas juvenis, punks, darks no espetáculo urbano. São Paulo: Scritta, 1994. ABRAMO, H. W.; FREITAS, M. V.; SPOSITO, M. P. (orgs.). Juventude em debate. São Paulo: Cortez, 2000.

ABRAMOVAY, M. et al. Gangues, galeras, chegados e rappers: juventude, violência e cidadania nas cidades da periferia de Brasília. Rio de Janeiro: Unesco, Instituto Ayrton Senna; Setur; Garamond, 1999.

ARENDT, H. La Crise de la culture. Paris: Galimard, 1954.

ARIAS, A. R. Avaliando a situação ocupacional e dos rendimentos do trabalho dos jovens entre 15 e 24 anos de idade na presente década. In: COMISSÃO NACIONAL DE POPULAÇÃO E DESENVOLVIMENTO. Jovens acontecendo na trilha das políticas públicas. Brasilia: CNPD/lpea, 1998, p. 519-541.

ARRIAGADA, I. Famílias vulnerables o vulnerabilidad de las famílias? In: CEPAL. Seminario Vulnerabilidad. Santiago de Chile, 2001. 
BERCOVICH, A. M.; DELLASOPA, E.; ARRIAGA, E. J'adjunte, mais je ne corrige pas: Jovens, violência e demografia no Brasil. Algumas reflexões a partir dos indicadores de violência. In: COMISSÃO NACIONAL DE POPULAÇÃO E DESENVOLVIMENTO. Jovens acontecendo na trilha das políticas públicas. Brasília: CNPD/Ipea, 1998. p. 293-362.

BOURDIEU, P. O Poder simbólico. Rio de Janeiro: Bertrand Brasil, 2001 .

BRASIL. Ministério da Educação e Cultura. INEP. Censo escolar 1998. Disponível em $<$ www.inep.gov.br>.

BRASIL. Ministério da Saúde. Sistema de informações sobre mortalidade. Disponível em: $<$ www.saude.gov.br $>$.

CARVALHO, J. A. Salvador: Cidade repartida-violência-diagnóstico e o fortalecimento da cidadania. Salvador: Comissão de Direitos do Cidadão da Câmara Municipal, 2001 .

CASTRO, M. G.; ABRAMOVAY, M. Cultura, identidades e cidadania: experiências com adolescentes em situação de risco. In: COMISSÃO NACIONAL DE POPULAÇÃO E DESENVOLVIMENTO. Jovens acontecendo na trilha das políticas públicas. Brasília: CNPD/lpea, 1998. p. $57 \mid-644$.

CASTRO, M. G. et al. Cultivando vida; desarmando violências: experiências em educação, cultura, lazer, esporte e cidadania com jovens em situação de pobreza. Brasília: Unesco, 2001 .

CEBRID. Levantamentos entre estudantes. Disponível em: <www.cebrid.drogas.com.br> Acessado em: 15/05/2001.

CEPAL. Juventud, población y desarrollo en América Latina y el Caribe: problemas, oportunidades e desafios. Santiago: Cepal, 2000.

COMISSÃO DE JUSTIÇA E PAZ DA ARQUIDIOCESE DE SALVADOR. A Outra face da moeda. violência na Bahia, COMISSÃO DE JUSTIÇA E PAZ DA ARQUIDIOCESE DE SALVADOR, 2000.

DUARTE, A. O Pensamento à sombra da ruptura: política e filosofia em Hannah Arendt. São Paulo: Paz e Terra, 200I.

FIBGE. Pesquisa de informações básicas municipais, 1999. Disponível em: <wuw.ibge.gov.br>. Acessado em: 15/05/2001.

. PNAD-1999: trabalho e rendimento. Disponível em: <www.ibge.gov.br>. Acessado em: 15/05/200 la.

. Diretoria de Pesquisas, Departamento de População e Indicadores Sociais. Pesquisa de informações básicas 1999. Rio de Janeiro: FIBGE, 1999.

FILGUEIRA, C. H. Estructura de oportunidades y vulnerabilidad social: aproximaciones conceptuales recientes. In: CEPAL. Seminario Vulnerabilidad. Santiago: Cepal, 2001. 
HOPENHAYN, M. La Vulnerabilidad reinterpretada: asimetrías, cruces y fantasmas, texto apresentado. In: Cepal. Seminario internacional de las diferentes expresiones de la vulnerabilidad social en America Latina y el Caribe. Santiago de Chile, 6/200 I . (mimeo)

JORGE, M. H. P. M. Como morrem nossos jovens. In: COMISSÃO NACIONAL DE POPULAÇÃO E DESENVOLVIMENTO. Jovens acontecendo na trilha das políticas públicas. Brasília: CNPD; Ipea, 1998. p.209-292.

LANDIM, L.; CATELA, L. S.; NOVAES, R. (coords.). Juventude, profissionalização e ação social católica no Rio de Janeiro. São Paulo: Iser, 1996.

MADEIRA, F. R. Quem mandou nascer mulher? Estudos sobre crianças e adolescentes pobres no Brasil. Rio de Janeiro: Rosa dos Tempos; Unicef, 1997.

. Recado dos jovens: mais qualificação. In: CNPD. Jovens acontecendo na trilha das politicas públicas. Brasília: CNPD; Ipea, 1998. p.427-496.

OLIVEIRA, J. C. et al. Evolução e características da população jovem no Brasil. In: CNPD. Jovens acontecendo na trilha das políticas públicas. Brasilia: CNPD; Ipea, 1998, p. 7-19.

PERALVA, A. Violência e o paradoxo brasileiro: democracia. Rio de Janeiro: Paz e Terra, 2000.

VIGNOLI, J. R. Vulnerabilidad demográfica em América Latina: qué hay de nuevo? In: CEPAL. Seminario Vulnerabilidad. Santiago: Cepal, 2001 .

WAISELFISZ, J. Mapa da violência: os jovens do Brasil. Rio de Janeiro: Unesco; Instituto Ayrton Senna; Garamond, 1998.

. Mapa da violência I/: os jovens do Brasil. Rio de Janeiro: Unesco; Instituto Ayrton Senna; Ministério da Justiça, 2000.

ZALUAR, A. Cidadãos não vão ao paraíso: juventude e política social. São Paulo: Unicamp, 1994. 